Volume 2 Issue 2, September 2017: pp. 119-128. Copyright @ LamLaj. Faculty of Law, Lambung Mangkurat University, Banjarmasin, South Kalimantan, Indonesia. ISSN: 2502-3136 | e-ISSN: 2502-3128. Open Access at: http://lamlaj.ulm.ac.id/web/

\title{
STEEP ROAD TOWARDS REGULATING FOR SUCCESS OF IMPLEMENTATION OF RECLAMATION AND POST MINING OF MINERAL AND COAL
}

\author{
Abdul Halim Barkatullah', Syaifudin², Mahyuni ${ }^{3}$, Ifrani ${ }^{4}$ \\ Faculty of Law, Lambung Mangkurat University, Jalan Brigjen \\ H. Hasan Basry, Banjarmasin 70123, South Kalimantan, Indonesia, \\ Phone/Fax:+62-8134843999,E-mail: halim.ulmbjm@gmail.com \\ Faculty of Law, Lambung Mangkurat University, Jalan Brigjen \\ H. Hasan Basry, Banjarmasin 70123, South Kalimantan Indonesia, \\ Phone/Fax:+62-81348439997E-mail: syaifudin.dr@gmail.com \\ Faculty of Law, Lambung Mangkurat University, Jalan Brigjen \\ H. Hasan Basry, Banjarmasin 70123, South Kalimantan Indonesia, \\ Phone /Fax:+62-81348439997E-mail:mahyuni60@gmail.com \\ Faculty of Law, Lambung Mangkurat University, Jalan Brigjen \\ H. Hasan Basry, Banjarmasin 70123, South Kalimantan, Indonesia, \\ Phone /Fax: +62-81348439997 E-mail: ifrani99@gmail.com
}

Submitted: 18/09/2017; Reviewed:28/09/2017; Accepted: 30/09/2017

\begin{abstract}
Coal and Mineral mining activities have a high risk of ecosystem changes that affect the environment, let alone the mining is carried out openly. In order to restore the condition of the land in such a way that it can function and to be effective in line with its allocation, the ex-mining area must be restored. Reclamation and post-mining activities shall be conducted by every holder of Mining Business Permit (IUP) Exploration and IUP Production. Holders of IUP Exploration must firstly prepare reclamation and post-mining plans in the permit process. The implementation of reclamation and post-mining activities by holders of IUP Production Operation and Special Mining Business Permit (IUPK) Production Operation must comply with the principles of: (1)protection and management of mining environment; (2) working safety and health; and (3) mineral and coal conservation. To determine the success of the land that has been reclaimed and the post-mining activities have been complied, if an evaluation has been made by the competent officials and it is stated that the reclamation and post-mining activitie shave been performed well in
\end{abstract}


accordance with prevailing regulations.

Keywords: Regulating; Reclamation and Post-mining; Mineral and Coal

\section{INTRODUCTION}

Natural resources management such as mineral and coal mining has a risk of the occurance of ecosystem change which shall affect the environment. Bigger risk may occur in a coal mine conducted by using open mining system and method. As a matter of fact, all coal mines in South are open cut.

Mining entrepreneurs both those whose permits are granted by Central Government (PKP2B) and by Local Government (IUP) are basically obliged to conduct environmetal study before performing exploration, exploitation, and operation production activities. The environmetal study is aimed at to conduct a study on the environmetal impacts that may happen during the activities period (exploration, exploitation, and operation production) as well as after the mining.

It cannot be denied that mining activities can cause irreversible destruction and pollution (irreversible damages) because once an area is opened for a mining operation, such area will have a potential of everlasting destruction. In the framework to restore the condition of the land in such a way it can function and be effective, such ex-mining land must be closed and restored.

In principle, mining reclamation is an effort to improve the land condition after the mining activities are finished. It is understood that the basic character of mining industry is destructive becuase its activities are to dig and change the landscapes, change the micro climate and the condition of environmental physical condition. Besides, mining industry also brings about positive impacts as a source of state foreign exchange, original regional revenue, creator of work opportunity, economic changes, and as agent of development in the region.

The government has enacted the obligation of reclamation to every holder of Mining Business Permit through Article 101 of Act Number 4 of 2009 and Government Regulation Number 78 of 2010 as its implenting regulation. This Government Regulation regulates in details the matters concerning the obligations of reclamation and post-mining activities. The provisions concerning reclamation are also regulated in the Regulation of the Minister of Energy and Mineral Resources Number 18 of 2008 concerning Reclamation and Closing of Mining.

After the mining activities are finished, the land must be immediately reclaimed. The goal is to avoid the possible potential of other destruction such as mining acid water, degration of land supporting capacity, even the occurance of wider land destruction.

The aims of mining area reclamation are to restore the ecosystem of ex-mining area through restoration of the land fertility and planting on the surface of the land. Other aims are to maintain that the land is stable, more productive, and improve the productivity of the ex-mining area. Finally, the reclamation can produce added value to the environment and create much better condition compared to the condition before the mining, environmental destruction, and so forth.

Statutory regulations related with mining oblige the mining companies to conduct reclamation upon the remaining mining area where they do the business. To provide the coercive effect to the mining entrepreneurs to 
perform the reclamation, they are obliged to deposit certain sum of money as reclamation guarantee which must be placed before the company performs the operation production activities. The obligation to submit the reclamation guarantee does not eliminate the obligation of the mining entrepreneurs to conduct reclamation.

In conducting reclamation by using the fund of reclamation guarantee which has been deposited by the mining entrepreneurs, the mining entrepreneurs must firstly submit a proposal of reclamasi model which shall be carried out. In this article the writers would like to find out the most suitable and comprehensive model of criteria in determining that the reclamation and postmining activities have been successfully performed.

\section{METHOD}

This research is normative legal research. Normative legal research is a process to find out a legal regulation, legal principles, and legal doctrines to cope with the legal issues being encountered. This kind of research is conducted in order to bring about argument, new theory or consept as prescription in solving the problems being coped with. ${ }^{1}$ The type of the research isued is legal systematics, utilizing primary and secondary legal resources. The technique of the analysis used is legal one, namely the analysis emphasizing the depth/quality of the legal resources, not from the quantity of the legal resources. The method of the analysis is by using deductive thinking logics.

1 Peter Mahmud Marzuki. 2005. Penelitian Hukum. Jakarta:Prenada Media, page. 35.

\section{ANALYSIS AND DISCUSSION}

\section{State Regulation on Reclamation and Post- mining Activities of Mineral and Coal}

The reclamation and postmining activities are forms of obligation of the mining business activities. Before conducting the reclamation and postmining activities, a mining permit is needed which is issued by the State (central, provincial or regency/municipal government) in line with her authority. ${ }^{2}$

The State's authority is not merely regarding right. Only the power vested by law can become the basis for the State to regulate. The right to regulate possessed by the State or power exercised by the State shows the existence of special taks of the State. The special task shall pay attention to the types of power in the State. ${ }^{3}$ Power always originates from formal authority or law i.e. the legal provision which regulates the granting of such authority. ${ }^{4} \mathrm{Ar}-$ ticle 33 of the 1945 Constitution is the constitutional ground for the State's domination power upon earth, water and natural resources therein. ${ }^{5}$

The State's dominating power based on the constitution is truly utilized for the people's welfare. These two aspects of norm are inseparable one to another, both are one

2 Irsan, dkk. "Kebijakan Reklamasi Pasca Tambang sebagai Bentuk Pengendalian Lahan Bekas Tambang Batubara Ditunjau dari Kewenangan Otonomi Daerah Sumatera Selatan”. ejournal.unsri. ac.id/index.php/jlsc/article/download/2597/1360 accessed on 18 July 2017.

3 Winahyu Erwiningsih . 2009. Hak Menguasai Negara Atas Tanah. Yogyakarta: Total Media, page, 278

4 Mochtar Kusumaatmadja. 2006. Konsep-Konsep Hukum Dalam Pembangunan. Bandung: Alumni, page. 5 .

5 Abrar Saleng. 2004. Hukum Pertambangan. Yogyakarta: UII Press, page. 22. 
systematic unity. ${ }^{6}$ The State's dominating power is instrumental. The sentence "to be utilized optimumly for the people's welfare" is the goal (objectivity) ${ }^{7}$ originating from the character of the constitution. The meaning of constitution is formation, what is formed is the state, so constitution means all kinds of main regulation concerning the main foundations to uphold the big building i.e. the state. ${ }^{8}$

The provision of Article 33 of the 1945 Constitution is based on the main ideas containing in the fourth paragraph of the Preamble of the 1945 Constitution, thus, Article 33 of the 1945 Constitution is norm forming of the values containing in the fourth paragraph of the Preamble of the 1945 Constitution among other things stating "... then therefrom to establish the Government of the Republic of Indonesia which shall protect the entire nation and the blood of Indonesia as well as to enhance the general welfare, to make the nation smart, and to participate in the world order based on freedom, peace, and social justice ...". In the last sentence of the fourth paragraph, namely, to actualize the social justice for entire Indonesian people is further known as the fifth principle of Pancasila (The Five Principles) and it is the legitimacy of the existence of the state.

The subject of the state's dominating right is the party or institution which is constitutionally or legally the party the most entitled to dominate particular object. The subject of the state's dominating right in the context of coal mining is the state (Article 33 paragraph

\footnotetext{
6 Ibid,

7 Ibid,

8 Anwar C. 2011. Teori dan Hukum Konstitusi. Malang : Intrans Publishing. second edition. page. 58
}

(3). ${ }^{9}$ In performing her function the state delegates it to state institution i.e. the executive/ government. The government has the power to make planning, formulate the regulations, implementation, management, utilization, and take the outcome from the mineral and coal deposits existing in the mining business areas in Indonesia.

The nature of the government's power is inherent in the aspect of power and responsibility, both in performing and giving responsibility upon the impelementation of the exercised power. The government as the subject of the state's dominating right must be based on its authority and has great function as follows:

a. powerful, competent and responsible upon the management, utilization, and taking of the outcome from the mineral and coal deposits.

b. To conduct legal forcing power starting from warning up to stoppage of all mining business activities (mineral and coal) which violate the regulations and ignore the principles of sustainable development..$^{10}$

The power is not the same as the formal authority and strength because someone who has physical strength in particular situation is unable to perform his power or his formal authority, so formal authority and physical strength are not the only source of power becuase there are still other sources of power such as money, economic power, morality and knowledge. ${ }^{11}$ Power is an absolute element in a legal society which is regulated and

\footnotetext{
9 Nandang Sudrajat. 2012. Teori dan Praktik Pertambangan Indonesia Menurut Hukum. Yogyakarta : Pustaka Yustisia, page. 27

$10 \quad$ Ibid, page. 67

11 Mochtar Kusumaatmadja. op.cit, page 7
} 
based on law. Analytically, power is function of regular society. ${ }^{12}$

The legal subject to dominate the deposits (mineral and coal) is the state exercised by the government as state institution guaranteed by the state constitution in Article 33 paragraph (3) of the 1945 Constitution which means there are other parties or only with the permission of the government since the power of controlling, regulating, and utilization is in the hand of the government. ${ }^{13}$

Whereas the object of the right of the state to dominate coal as natural resource is something which becomes the target and as the object of right is possession, power, and authority. Power is the ability, strength, capacity to do something. Dominate means powerful to/ authorized to. So the object is something or thing which becomes the undertaking or target, performed by particular activity for taking its benefit. Thus, the object of the right of the state to dominate in the context of mining deposits is something or thing to be undertaken. Generally, object (zaak) is anything which can become the object of the right of ownership. Right of ownership here cane be in a form of thing/object and rights such as copy right, patent, and so forth. ${ }^{14}$

Civil law views object as tangible object such as motor vehicle, land etc. and intangible object regulated in separated acts. ${ }^{15}$ The object of the state's dominating right here in the context of land and outcome of the mining activity including coal and mining deposits which should be undertaken to the greatest for

\footnotetext{
12 Ibid

13 Nandang Sudrajat. Op.Cit, page. 28

14 Djaja S Meliala,. 2007. Perkembangan Hukum Perdata Tentang Benda dan Hukum Perikatan. Bandung : Nuansa Aulia, page. 16.

the people's welfare. ${ }^{16}$ Taking into account the meaing of The object of the state's dominating right in the context of mining deposits there are two kinds, namely, mining deposits and people. ${ }^{17}$ Mining deposits ais classified as main object of the source of the state revenue, while people is the target, and the utilization/outcome of the coal deposits is used as living source of the nation and the state. Besides as the object, actually the people can act as subject in their capacity as performers of mining business activity through permits issued by the government.

To place the people as the subject of mining deposit undertaking requires that the people are not merely as the actors of economic development but also all aspects and goals of wider development. ${ }^{18}$ According to Nandang, development in the context of utilization of mining deposits must be aimed at:

a. Accelerating the national economic stability;

b. Improving the capacity or skill of the people as actors of mining business activity as part of nature resources development as a whole;

c. Increasing the nation's independence because through the people in their capacity as actors of mining business activity, of course there will be no capital flight from the undertaking of the deposit, on the contrary it will bring savings and domestic capital capacity. ${ }^{19}$

Coal mining regulation in Indonesia is part of mining law which means law which regulates the digging or mining of ores and minerals in

\footnotetext{
16 Nandang Sudrajat. Op.Cit, page. 29.

17 Ibid,

18 Mochtar Kusumaatmadja. op.cit, page 19.

19 Ibid,
} 
the ground. This definition is only focused on the activities of the digging or mining of ores. ${ }^{20}$

The scope of the study of mining law consists of general mining and oil and natural gas mining. General gas is mining of deposits other than oil and natural gas. General mining is classified into five groups i.e. radioactive mineral mining, metal mineral mining, non logam mineral mining, coal mining, peat and solid bitumen, and geothermal mining. ${ }^{21}$

Mining Business Permit (IUP) is legality for management and undertaking of mining deposits used by business entities such as national private company and foregin business entity, cooperative, and corporation. According to Article 36 paragraph (1) of Act Number 4 of 2009, Mining Business Permit (IUP) comprised two stages, namely, IUP Exploration and IUP Operation Production.

Technically, IUP Exploration consists of the following activities: ${ }^{22}$
a. General Survey;
b. Exploration;
c. Feasibility Study.

The simplication of permit process atu general survey stage, besides it atractive because the bueaucracy of permit, technically it can be understood beause for certain mining deposit, if we refer to the nature and if we refer to the nature and characteristics of the mining deposits, some of the technical stage can be carried out, thus, legally it is not contrary to the Act. The legality of the mining or exploitation acording to Act Number 11 of 1967 is issued in a form of Mining Permit

20 Salim HS.Op.Cit, page.7

21 Ibid, page. 10-11

22 http://hukum pertambangan.com, accessed on 30 March 2017
(KP) Exploitation, has been simplied and the term used is Mining Business Permit (IUP) Operation Production, which the scope of leglity comprises the mining business activities as follows:

a. Construction or preparatory work;

b. Mining;

c. Processing and purification;

d. Tranportation and sale.

Although there has been simplification in the type and stage of the legality, but Act Number 4 of 2009 applies norms of restriction which were not regulated in Act Number 11 of 1967 . The restrictions are as follows:

a. General restriction:

1) IUP is only valid for one type of mineral with application;

2) If other mineral are found and the IUP holder is interested in such minerals, he must apply for new IUP for the said mineral and shall be given priority therefor;

3) New IUP is applied to the minister, governor, regent/mayor in line with their authority;

4) If IUP holder is not interested, he is oblied to look after and maintain the said value, and the management of the undertaking can be given to other party.

b. Restriction or regulation for IUP metal mineral:

1) IUP eksploration has the following restrictions:

a) The period of the activities is granted for maximum eight years;

b) The size of the area (WIUP) is 5,000 - 100,000 hectares. 
2) IUP Operation Production has the following restrictions:

a) The period of the activities is granted for maximum 20 years and extendable for 2 x 10 years;

b) The size of the area (WIUP) is maximum 25,000 hectares.

c. Restriction or regulation for IUP nonmetal mineral:

1) IUP Eksploration has the following restrictions:

a) The period of the activities is granted for maximum 3 years, and non-metal of particular type is for maximum 7 years.

b) The size of the area (WIUP) is 500 - 25,000 hectares.

2) IUP Operation Production has the following restrictions:

a) The period of the activities is granted for 10 years and extendable for 2 x 5 years;

b) For non-metal mineral of particular type, undertaking for 20 years is granted, and extendable for 2 x 10 years;

c) The size of the area (WIUP) is maximum 5,000 hectares.

d. Restriction or regulation for IUP rock mining:

1) IUP Exploration has the following restrictions:

a) The period of the activities is granted for maximum 3 years;

b) The size of the area (WIUP) is 5 - 5,000 hectres.

2) IUP Operation Production has the following restrictions: a) The period of the activities is granted for 5 years and extendable for 2 x 5 years;

b) The size of the area (WIUP) is maximum 1,000 hectares.

e. Restriction or regulation for IUP coal mining:

1) IUP Exploration has the following restrictions:

a) The period granted for survey is maximum 7 years;

b) The size of the area (WIUP) is 5,000 - 50,000 hectares.

2) IUP Operation Production has the following restrictions:

a) The period of the activities is granted for 20 years and extendable for 2 x 10 years;

b) The size of the area (WIUP) is maximum 15,000 hectares.

f) Restriction or regulation for IUP radioactive mining:

Radioactive mineral is strategic mineral not only for the national perspective, but also international point of view, besides it is also sensitive to international issues. In writers' opinon, perhaps based on such consideration why Act Number 4 of 2009 does not specially regulates the management and udertaking of this mineral and the management is adjusted with the related legislation.

The form of the decision of this permit is the continuation of the stage after the IUP and shall be granted in accordance with the authority of the minister, governor, mayor, and regent, although after the enactment of Act Number 23 of 2014 concerning Regional Government, mining has become the author- 
ity of the Central Government and Governor. The procedure of permit making should comply with the procedure of the writing of a permit decision such as : in the letter of decision the first page must have the symbol of Garuda Pancasila (the state's idelogy) because the decision is granted on behalf of the government and under it is the number of the decision, the authority of the official according to the legislation stipulated in the sentences of the decision of the minister/ governor concerning the gratting of the permit of IUP Operation Production to PT. A (as applicant).

In the second point of the IUP decision, to the IUP holder is granted the right to carry out sale/marketing of the coal because the holder is given the right as the owner of the coal (Article 92 of Mineral and Coal Act).

On the contrary the third point of the permit or letter of decision, it not allowed to to be transferred or sold (see Article 93 paragraph (1) of Mineral and Coal Act) and it is only permitted to transfer th shares, thus the control of the company changes (see Article 93 paragrap (3) of Mineral and Coal Act), so the nature of civil law regulution is more dominant in this matter.

In practice there are no differences of permit granting mechanism between Mining Permit (KP) and the one applied for new permit in of Mineral and Coal Act. There is no impact to the making of the deed because during the period of KP system, the transfer of shares was also regulated, namely, with the approval of the government.

The distinctions can been found only in the classification of mineral and coal, in the past the classification was group A, B and C. With regard to radioactive mineral it should be regulated by the government including the transfer of shares.
In Mineral and Coal Act, Contract of Work, PKP2B, and Production Sharing are equalized to Special Mining Business Permit (IUPK), namely, special mining permit granted by the government to the investor, so there is no longer production sharing system, instead using total financial revenue through taxes, regional levies, and fees for seriousness guarantee and reclamation. ${ }^{23}$

Several matters need to get attention with regard to in connection with the obligation of reclamation guarantee as follows:

\section{Component of Reclamation Cost}

Reclamation Cost Plan is made every year for a period of 5 (five) year which calculation shall cover direct and indirect costs using the currect of Rupiah or US Dollar. Direct costs are among other things, land usage, revegetation, prevention and handling of mining acid water, and civil works. Indirect costs consist of mobilization and demobilization, reclamation activity planning, administration and third party's profit as contractor for the performance of the reclamation, and supervision.

2. Forms of Reclamation Guarantee

Reclamation Guarantee is made in several forms i.e.:

a. Time Deposit, placed at the government bank in Indonesia under the name of the Minister, Governor or Regent/Mayor qq. The company concerned, with the period of guarantee in line with the reclamation schedule.

b. Bank Guarantee, issued by the government bank in Indonesia or branch

23. Ibid, 
of foreign bank in Indonesia or government-owned guarantee institution, with the period of guarantee in line with the reclamation schedule;

c. Insurance issued by by the government bank in Indonesia Indonesia or branch of foreign bank in Indonesia or government-owned guarantee institution, with the period of guarantee in line with the reclamation schedule; or

d. Accounting Reserve, can be placed if the Company meets one of the following requirements: 1 . A public company registered at the stock exchange in Indonesia or outside Indonesia; or 2. A company having paid up capital not less than US \$ 25,000,000.00 (twenty five million United States Dollars) as stated in the financial report which has been audited by public accountant registered at the Departement of Finance. The company placing reclamation guarantee in a form of Accounting Reserve is obliged to submit annual financial report which has been audited by public accountant. The form of the reclamation guarantee placed by a mining company shall be determined by the Minister, Governor or Regent/Mayor according to their respective authority.

\section{Placement of Reclamation Guarantee}

Placement of reclamation guarantee must be made before the company commence the exploitation/operation production activities, however such placement does not eliminate the company's obligation to conduct reclamation. In the event that the reclamation requires bigger cost than the determined reclamation guaran- tee, the company is responsible to cover the shortage of the cost. This is also valid for the implementation of reclamation by the third party appointed by the Minister, Governor or Regent/Mayor, in case the mining company is considered to be unsuccessful to realize the reclamation.

4. Disbursement of Release of Reclamation

Guarantee

Request for the disbursement of reclamation guarantee in a form of Time Deposit or release of reclamation guarantee in the form of Bank Guarantee, Insurance, and Accounting Reserve can be proposed step by step in line with the stage of the implementation of the reclamation, by attaching reclamation implementation report. Such request should be addressed by the company to the Minister, Governor or Regent/Mayor according to their respective authority, then they will make evaluation in order to determine the amount of the reclamation guarantee to be disbursed or released. For the sake of the evaluation, the Minister, Governor or Regent/ Mayor can conduct field inspection in oder to evaluate the success of the reclamation which late on must be written in a form of report.

Reclamation activity regulated in the legislation emphasizes an on the restoration and improvement of the environmental condition without touching significantly the social aspect. While the social impact sufferred by the community around the mining cannot be ignored because it will deny the meaning contained in the Preamble of the 1945 Constitution Article 33 previously mentioned, namely, to reach the greatest welfare of the people. The reclamation model existing so far must 
be completed with a reclamation model which covers the reclamation in more comprehensive social sector and is able to close the empty holes left by the mining companies.

Act Number 4 of 2009 concerning Mineral and Coal Mining defines reclamation as an activity carried out during the stage of the mining business to manage, restore, and repair the environmental condition and ecosystem. While postmining activity is defined as after the end of some or all mining business activities in order to restore the natural environmental function and the social function.

The government has enacted the reclamation obligation to every holder of Mining Business Permit through Article 101 of Act Number 4 of 2009 and Government Regulation (PP) Number 78 of 2010 as its implementing regulation. This GR regulates in deteails the reclamation and postmining obligations. The provisions on reclamation is also regulated in the Regulation of the Minister of Energy and Natural Resources Number 18 of 2008 concerning Reclamation and Mining Closing.

One of the articles in PP 78 of 2010 stipulates that the reclamation activity is obliged to every holder of IUP Exploration and IUP Production. The said reclamation activity must be performed by paying attention the environmental aspect, work safety/health, and mineral and coal conservation (specially to the holder of IUP Production).

The holder of IUP Exploration must firstly make Work Program and Budget for the exploration which shall also cover reclamation plan for the said stage. The reclamation and postmining plans must be proposed for obtaining the government's approval, together with the application of the IUP Production. Thus, Reclamation Plan at the time of Permit is very determinant on how the Reclamation and Budgeting system and the implementation of the reclamation and postmining activities shall be conducted by the mining company.

\section{Criteria of Success in the Implementation of Reclamation and Postmining Activities of Mineral and Coal Mining}

The mining entrepreneurs both through the permit issued by the Central Government (PKP2B) and by Regional Government (IUP) are basically obliged to conduct environmental study before performing the exploration, exploitation, and operation production activities. The environmental study is aimed at conducting study on environmetal impact which will occur both at the time performing the activities stage (exploration, exploitation, and operation production) and postmining environmental impact.

The mining entrepreneur has the obligation to perform reclamation, namely, the effort to conduct environmental restoration which ecosystem has been effected, and the said obligation is marked with the obligation to deposit certain amount of fund as reclamation guarantee.

Reclamation activity is carriout out after the mining activity is considered to be finished and with the reclamation it is expected that the ex-mining area can be restored and futher it can be reused for other activity ob the society and the government.

The realization of reclamation is optimumly pursued to involve the surrounding 
community, higher education, and NGOs in charge of environmental sector and giving priority to local elements, so all parties feel to have collective responsibility for the improvement of the environment for the future generation.

Reclamation is the activity aimed at improving or managing the land use effected as a result of mining business activity so that it can function and be effective in line with its use. Some matters must be considered in relation with the realization of reclamation as follows:

1. Reclamation is mandatory to be performed at the latest 1 (one) month after there is not mining business activity in the effected land which include ex-mining land. With the enforcement of the said Ministerial Regulation, the Decision of the Minister of Mining and Energy concerning Prevention and Handling of Environmental Destruction and Pollusion in General Mining Business Activity, and Decision of the Minister of Energy and Mineral Resources Number 1453.K/29/ MEM/2000 concerning Technical Guideline of Governmental Task in the General Mining Sector, as long as he provision is related with reclamation and mining closing, is revoked and declared no longer in force.

2. Land outside ex-mining which shall consist of: (1) topsoil filling; (2) raw material/production stacking; (3) transportation roads; (4) processing/purification factory/ installation; (5) office and housing; (6) port/jetty. The said realization of reclamation should be reported by the mining company annually to the Minister, Governor, or Regent/Mayor, in line with their authority.
3. In the event that the Minister, Governor, or Regent/Mayor are in the opinion that the company does not fulfil the criteria of success in the implementation of the reclamation, both based on the evaluation of the report and or based on the field evaluation, the Minister, Governor, or Regent/ Mayor in line with their authority can appoint the third party to carry out the reclamation activity by using the Reclamation Guaantee as further described hereunder.

4. Reclamation is conducted by the mining company in accordance with the Reclamation Plan, including the amendement of the Reclamation Plan which has been approved by the Minister, Governor, or Regent/Mayor pursuant to their authority. The Reclamation Plan is made for every 5 (five) year realization with the annual details which shall comprise the land use before and after the mining, land clearing plan, reclamation plan, and reclamation budget plan

Based on the said description it can be inferred that the effort to restore the land condition in order to function in line with its use through reclamation, is not simply the responsibility of the mining company, but also the resposibility of the government in this matter the Minister, Governor, or Regent/Mayor because they are the ones who do the evaluation and approval of the Reclamation Plan, and at the same time to conduct supervision on the realization of the reclamation by the mining companies.

Reclamation cost is needed to restore the condition of the land shall be borne by the mining company. It is some part of the cost of environmental management arising during the production state. Is is a part of production burdens which constitutes one of the reducing 
factor of the business sale (income originating from the mining outcome of the company ) to show the gross profit (loss).

In order to guarantee the mining company's complience to perform the reclamation in line with the Reclamation Plan, the mining company is obliged to prepare Reclamation Guarantee which amount is in accordance with Reclamation Budget Plan which has got approval from the Minister, Governor, or Regent/Mayor pursuant to their authority. The provision on the oblogation to allocate reclamation guarantee can also give confidence to the society and related institution, in relation with the ability of the mining company in giving confidence to actualize the environment management plan, especially in the implementation of the reclamation of ex-mining land.

Article 24 paragraph (1) of the Minister of Energy and Mineral Resources Number 18 of 2008 stipulates that reclamation guarantee must be placed by the company before the company perform the exploitation/operation production. This regulation does not regulate the reclamation guarantee in exploition activity. It is necessary to carry out technical study whether in the exploration activity stage will not cause enviromental damage so the government does not regulate reclamation guarantee for this phase.

The criteria of Reclamation and Postmining success must be in conformity with the matters regulated in statutory regulations among other things:

1. Government Regulation Number 78 of 2010 concerning Reclamation and Postmining. In order to reach the sustainable development, the mining business activity must parformed by taking into consideration the principles of environment, transparancy, and society's participation.

If the mining activity is correctly undertaken it can bring about negative impact to the environment, especially significant disturbance to the balance of the land surface. The environmental impact of the mining activity are among other things, decrease of land productivity, land becomes solid/compact, erosion and sedimentation, land movement or landslide, disturbance to the flora and fauna, hinderance to public health, and micro climate change. Thefore, it is necessary to conduct the appropriate reclamation and postmining activities integrated with the mining activity.

Reclamation activity must be performed as soon as possible and it is not neccessary to wait until the entire process of the mining has been completed. The best practice of environmental management in mining requires continuous and intergrated process in all stages of the mining acitivity which cover some or all activity stategs in the framework of study, menagement, and undertaking of mineral or coal consisting of general survey, exploration, feasibility study, construction, mining, processing and purification, transportation and sale, as well as postmining activity.

Correct planning and impelementation is a sequence of sustainable and environmemtal oriented mining management, so it will reduce the negative environmental impact of the mining business.

2. Government Regulation Number 24 of 2012 concerning Amendment to Government Regulation Number 23 of 2010 concerning Implementation of Mineral and Coal Mining Business Activities; 
3. Regulation of the Minister of Energy and Mineral Resources Number 18 of 2008 concerning Reclamation and Mining Closing;

4. Regulation of the Minister of Forestry Number P.60/Menhut-II/2009 concerning Guideline on the Evaluation on the Success of Forest Reclamation;

5. Regulation of the Minister of Forestry Number Number P.4/Menhut-II/2011 concerning Guideline on Forest Reclamation;

6. Regulation of the Minister of Energy and Mineral Resources Number 02 of 2013 concerning Supervision to the Implementation of Mining Business Management Performed by Provincial Government and Regency/Municipal Government;

7. Regulation of the Minister of Energy and Mineral Resources Number 07 of 2014 concerning Implementation of Reclamation and Postmining in the Activities of Mineral and Coal Mining Business;

8. Regional Regulation of South Kalimantan Province Number 1 of 2013 concerning Reclamation of Coal Postmining in South Kalimantan.

This Regional Regulation is made in the effort to restore the quality of the supporting power of the environment, so reclamation is strategic step needs to be conducted for the sake of the society and regional future, and thus, the management should pay attention to and safeguard the sustainability of the function of environmental component therein.

Reclamation and Postmining in this Regional Regulation also regulates the document of reclamation plan, containing the timeline of the handling adjusted with the mining period, land use prior and postmining, land clear- ing plan, reclamation program to the effected land, which comprise ex-mining land and ouside ex-mining land, both temporary and permanent, the criteria of the success is made by containing the indicators of the standard of success in land management, revegetation, civil work and final handling.

Law must be able to regulate the impact of development, law is subsystem in the living system in the state, ${ }^{24}$ such as in the sector of mining, especially mineral and coal mining dealing with environment and public social welfare, namely, with presence of coercive element of the law, so every business entity possessing the IUP in the sector of coal mining undertaking must realize its task and responsibility to the social issue and public economy around the mining area (WIUP). This is not other than in the framework to assist the government to eradicate the poverty.

Thus, the task of the government to make the mechanism in the field of mining policy which goal is to enhance the public welfare, helped by private business entities having mining business permit, in order to actualize the state goal especially to bring welfare, and educate the nation. It means that the state must be able to impelement the development by directing to the substance which shall be reached intergratedly and based on precise planning in the sector of mining, reclamation, and postmining.

This policy must be based on the realization of people's welfare and prosperity and the sustainability of the environmental function which constitute integral part of the gover-

24 Teguh Prasetyo dan Abdul Halim Barkatullah. 2014. Filsafat, Teori dan Ilmu Hukum: Pemikiran Menuju Masyarakat yang Berkeadilan dan Bermartabat, Jakarta : PT. Raja Grafindo Persada, page. 314. 
ment duties both central and regional level.

The impelemnation of reclamation and postmining by the holder of IUP Operation Production and IUPK Operation Production is obliged to meet the principle of: (1) protection and management of mining environment; (2) work safety and health; and (3) conservation of mineral and coal.

Holder of IUP Exploration and IUPK Exploration before conducting exploration activity is obliged to make reclamation plan based on the environmentl document in line with the provisions of the legislation in the field of environmental proctetion and management. Reclamation plan is included in work progam and budget of the exploration. Reclamation plan and postmining plan are proposed together with application for IUP Operation Production and IUPK Operation Production.

Precise planning and implementation are series of environmentally oriented and sustainable mining management so they will reduce the negative impact of mining business activities. They are related with the end of postmining land, postmining program, organization, criteria of the success of postmining, and postming cost. Nevertheless, in preparing the postmining plan, the holder of IUP and IUPK must consult with the government institution and/or regional government institution in charge of mineral and/or coal mining, related institutions, and the community. It should be taken in order to accomodate the interest of the government (central and regional) and the community. ${ }^{25}$

25 Heriyansyah. 2015. "Implementasi Peraturan Pemerintah Nomor 78 Tahun 2010 Tentang Reklamasi Dan Pascatambang" eJournal Ilmu Pemerintahan, 3 (1) : 520-534 ISSN 0000-0000, ejournal.ip.fisip-unmul.ac.id. hlm. 526. http:// ejournal.ip.fisip-unmul.ac.id/site/wp-content/
The holders of IUP Operation Production and IUPK Operation Production are obliged to carry out reclamation and postmining activities in line with the reclamation plan and postmining plan until they fulfil the criteria of success. Those who have finished the implementation of postmining activity must hand over the postmining land to the entitled party pursuant to the statutory regulations.

Reclamation is insaparable part of every mining activity or stage. That's why reclamation plan is integrated part of mining plan, both short term and long term. Survey biodiversity and managing procedure of biodiversity have been made to guarantee the performance of this activity. Land management prior to the mining is conducted by utilizing special instrument and vehicle for the compacting so the the seeds of the plants on the said land can grow again in the spreading land. Then the land is separated and re-spreaded in the rehabilitating areas or being kept for the time being. Preparation of the reclamation area is conducted by building dump area. It is carried out in the ex-mining area or other areas for dumping by paying attention to the geotechnical and environmental aspects. ${ }^{26}$

So reclamation process of mineral and coal mining is not necessarily to return the land to the original condition before the mining. Instead, the reclamation activity conducted along the stage of mining stage is aimed at managing, restoring, and improving the environmental quality and ecosystem so the land

uploads/2015/04/e-journal\%20hery\%20(04-0215-03-45-02).pdf accessed on 18 July 2017.

26 Abrar Saleng Nurlaela, Farida Patittingi. "Tanggung Jawab Hukum Reklamasi Lahan Bekas Pertambangan PT. Kaltim Prima Coal di Kabupaten Kutai Timur”, hlm. 7. pasca.unhas. ac.id/ jurnal/files/5471fb8fd8a2329c216c804f851 15bd6.pdf. accessed on 18 July 2017. 
can function again in accordance with its use.

The postmining activity must be implemented with planning, systematic, and sustainable after the end of some or all of the mining business activity in order tp restore the function of natural environment and social fucntion according to the local condition in the entire area mining area.

To determine the success of the reclaimed and postmining area is if the activities have been evaluated by the Minister or Governor in accordance with their authority, and it has been stated that the reclamation and the postmining have been carried out in line with the the planning which has been previously planned at the time of permit or the reclamation and postmining have been evaluted and certified to have met the criteria of success by the the competent institution.

\section{CONCLUSION}

Regulation in reclamation and postmining activities by obliging every holder of Mining Business Permit (IUP) Exploration and IUP Production. Holder of IUP Exloration must firstly make Work Plan and Budget for the exploration stage which shall include reclamation plan, the reclamation and postmining must obtain the approval of the government, together with the application for IUP Production. So Reclamation Plan at the time of the permit is very determinant on how the reclamation system and the budget for the implementation of the reclamation and postmining to be carried out by the mining company.

The creteria in determining the success in the implementation of reclamation and postmining of mineral and coal by the holder of IUP Operation Production and IUPK Operation Production is to perform the reclamation and postmining must be in accordance with the reclamation plan and postmining plan until it fulfils the criteria of success. To determine the success of the land which has been reclaimed and the postmining handling is conducted by through evaluation by the competent official and it is declared that the reclamation and postmining have been perforned and have fulfilled the creteria of success.

\section{BIBLIOGRAPHY}

C, Anwar . 2011. Teori dan Hukum Konstitusi. Malang : Intrans Publishing, second edition.

Erwiningsih, Winahyu. 2009. Hak Menguasai Negara Atas Tanah. Yogyakarta : Total Media.

Fetterman, David M. 1998. Ethnography Step by Step. London : Sage Publishing. http:// hukum pertambangan.com, downloaded on 30-03-2017

Heriyansyah. "Implementasi Peraturan Pemerintah Nomor 78 Tahun 2010 Tentang Reklamasi Dan Pascatambang" eJournal Ilmu Pemerintahan, 3 (1) 2015: 520-534 ISSN 0000-0000, ejournal.ip.fisip-unmul.ac.id. hlm. 526. http:// ejournal.ip.fisip-unmul.ac.id/site/wpcontent/uploads/2015/04/e-journal\%20 hery\%20(04-02-15-03-45-02).pdf accessed on 18 July 2017.

Irsan, dkk. "Kebijakan Reklamasi Pasca Tambang sebagai Bentuk Pengendalian Lahan Bekas Tambang Batubara Ditunjau dari Kewenangan Otonomi Daerah Sumatera Selatan". ejournal.unsri.ac.id/index.php/ jlsc/article/download/ 2597/1360 accessed on 18 July 2017.

Kusumaatmadja, Mochtar. 2006. KonsepKonsep Hukum Dalam Pembangunan, Bandung : Alumni. 
Marzuki, Peter Mahmud. 2005. Penelitian Hukum. Jakarta:Prenada Media.

Meliala, Djaja S. 2007. Perkembangan Hukum Perdata Tentang Benda dan Hukum Perikatan. Bandung : Nuansa Aulia.

Nurlaela, Abrar Saleng, Farida Patittingi. Tanggung Jawab Hukum Reklamasi Lahan Bekas Pertambangan PT. Kaltim Prima Coal di Kabupaten Kutai Timur". hlm. 7. pasca.unhas.ac.id/jurnal/files/54 71fb8fd8a2329c216c804f85115bd6. pdf. Accessed on 18 July 2017.

Prasetyo, Teguh, dan Abdul Halim Barkatullah. (2014). Filsafat, Teori dan Ilmu Hukum: Pemikiran Menuju Masyarakat yang Berkeadilan dan Bermartabat, Jakarta : PT. RajaGrafindo Persada.

Saleng, Abrar. 2004 Hukum Pertambangan, UII Press, Yogyakarta.

Sudrajat, Nandang. 2012. Teori dan Praktik Pertambangan Indonesia Menurut Hukum, Yogyakarta : Pustaka Yustisia.

\section{Legislation}

1945 Constitution.

Act Number 4 of 2009 concerning Mineral and Coal Mining.

Government Regulation Number 78 of 2010 concerning Reclamation and Postmining.

Government Regulation Number 24 of 2012 concerning Amendment to Government Regulation Number 23 of 2010 concerning Implementation of Business Activities of Mineral and Coal Mining.

Regulation of the Minister of Energy, Natural Resources, and Mining Number 18 of 2008 concerning Reclamation and Closing of Mining;

Regulation of the Minister of Forestry Number P.60/Menhut-II/2009 concerning
Guideline for Evaluation of the Success of Forest Reclamation.

Regulation of the Minister of Forestry Number P.4/Menhut-II/2011 concerning Guideline for Forest Reclamation;

Regulation of the Minister of Energy, Natural Resources, and Mining Number 02 of 2013 concerning Supervision to Implementation of Mining Business Management Conducted by Provincial Government and Regency/Municipal Government.

Regulation of the Minister of Mineral Resourcesof the Republic of Indonesia Number 07 of 2014 concerning Implementation of Reclamation and Postmining Activities in Business Activities of Mineral and Coal Mining.

Regional Regulation of South Kalimantan Province Number 1 of 2013 concerning Land Reclamation and Postmining Activities of Coal in South Kalimantan. 